\title{
INVESTIGATION OF THE ATTITUDES AND PURCHASING BEHAVIOR OF THE STUDENTS TAKING GREEN AND REVERSE LOGISTICS COURSE TOWARDS GREEN PRODUCTS: THE CASE OF NECMETTIN ERBAKAN UNIVERSITY
}

\author{
Selda BAŞARAN ALAGÖZ ${ }^{1}$, Abdullah Oktay DÜNDAR ${ }^{2}$, Aygen SEV ${ }^{3}$
}

\begin{abstract}
In this study, it is investigated whether there is a significant difference between the attitudes and purchasing behavior of the students taking and not taking green and reverse logistics course. The sample of the study consists of students studying at the Department of Transportation and Logistics, Faculty of Applied Sciences, Necmettin Erbakan University in 2018-2019 academic year. In the study, a questionnaire consisting of 25 questions was applied to the students who took Green and Reverse Logistics courses. It was investigated whether there was a significant difference between the attitudes and the purchasing behavior of the students taking and not taking this course towards green products. As a result of the research, a significant difference was found in the attitudes of the students who took the green and reverse logistics course and the students who did not take the course towards the recycled products. Students who take the green and reverse logistics course are more moderate about recycled products and are interested in purchasing. One of the factors of this is the recycling issue in the course content and the contribution of recycled products to the environment. As a result of the research questions on green purchasing behavior which is another dimension of the research, no significant difference was observed between the students taking and not taking the course. Green purchasing behavior comes to the forefront with more material elements than environmental awareness. With the expression among the questionnaire questions "I take into account the price factor", it was seen that the majority of the participants are looking at the price rather than the environmental impact of the products.
\end{abstract}

Keywords: Reverse Logistics, Recovery, Green Product, Consumer Purchasing Behavior

Jel Classification: I21, L91, M31

\section{YEŞİL ve TERSINE LOJISTIKK DERSİ ALAN ÖĞRENCİLERIN YEŞİL ÜRÜNE YÖNELIKK TUTUMLARININ ve SATIN ALMA DAVRANIŞLARININ INCELENMESI: NECMETTIN ERBAKAN ÜNIVERSITESİ ÖRNEĞİ}

$\ddot{O} z$

$\mathrm{Bu}$ çalışmada tersine ve yeşil lojistik ile ilgili eğitim alan ve almayan öğrencilerin yeşil ürüne yönelik tutumları ve satın alma davranışları arasında anlamlı bir farklılığın olup olmadığı araştırılmaktadır. Çalışmanın örneklem kütlesi Necmettin Erbakan Üniversitesi Uygulamalı Bilimler Fakültesi Ulaştırma ve Lojistik Bölümünde 2018-2019 eğitim öğretim yılında okuyan öğrencilerden oluşmaktadır. Çalışmada Yeşil ve Tersine Lojistik dersi alan ve almayan öğrencilere 25 sorudan oluşan anket uygulanmıştır. Bu dersi alan ve almayan öğrencilerin yeşil ürünlere yönelik tutumları ve yeşil ürüne yönelik satın alma davranışları arasında anlamlı bir farklılığın olup olmadığı araştıılmıştır.

1 Prof. Dr. Selda BAŞARAN ALAGÖZ, Necmettin Erbakan University, Faculty of Applied Sciences, Department of Transportation and Logistics, Konya, Turkey, sbalagoz@erbakan.edu.tr ORCID: 00000002-4615-5337

2 Asst. Prof. Abdullah Oktay DÜNDAR, Necmettin Erbakan University, Faculty of Applied Sciences, Department of Transportation and Logistics, Konya, Turkey, aodundar@erbakan.edu.trORCID: 00000002-8508-165X

3 Aygen SEV, Necmettin Erbakan University, Social Sciences Institute, International Marketing and Logistics Management, aygensevv@ gmail.com ORCID:0000-0001-6675-6239 
Yapılan araştırma sonucunda yeşil ve tersine lojistik dersini alan öğrenciler ile dersi almayan öğrencilerin geri dönüştürülmüş ürünlere yönelik tutumlarında anlamlı bir farklılığa rastlanılmıştır. Yeşil ve tersine lojistik dersi alan öğrenciler geri dönüştürülmüş ürünlere yönelik daha ılımlı yaklaşmaktadır ve satın alma düşüncesi içerisine girmektedir. Bunun etkenlerinden birisi ise ders içeriğinde yer alan geri dönüşüm konusu ve geri dönüştürülmüş ürünler ile çevreye sağlanacak katkıdır. Dersi alan ve almayan öğrenciler arasında yapılan araştırmanın bir diğer boyutu olan yeşil satın alma davranışıyla ilgili inceleme sorularından varılan sonuçta ise dersi alan ve almayan öğrenciler arasında anlamlı bir farklılık gözlenmemiştir. Yeşil satın alma davranışında çevre bilincinden daha fazla maddi unsurlar ön plana çıkmaktadır. Anket soruları arasında yer alan fiyat faktörünü dikkate alırım ifadesi ile katılımcıların büyük çoğunluğunun ürünlerin çevrede yarattığı etkiden çok fiyatına baktığı ön plana çıkmıştır.

Anahtar Kelimeler: Tersine Lojistik, Geri Kazanım, Yeşil Ürün, Tüketici Satın Alma Davranış1

Jel Kodları: I21, L91, M31

\section{Introduction}

Human beings will continue to consume as long as they exist. In parallel with the rapid rise of the world's population, the needs of people are increasing and consumption is also increasing with these needs. The increase in consumption brings about environmental pollution. After each product is consumed, its packaging, residues or eventually itself becomes waste. Non-recyclable productions made unconsciously and wastes continue to become a problem every day. Although environmental policies sometimes contradict the cost reduction policies of the companies, it is inevitable to make the necessary arrangements in line with the expectations of the customers.

With the adoption of the concept of environmental awareness, human beings tend to consume green products (environmentally friendly products). Demand for green products continues to increase every day with the improvement of people's environmental awareness. As a result of this improvement, companies start to design recyclable and reusable products while they are in the design stage before they start production. Among the reasons why producers turn to green products are less environmental damage, recycling of products and lowering costs with the efficient use of scarce resources.

In this study, basic information on reverse logistics and green product purchase has been given and, as a result of the questionnaire applied to the students of Konya Necmettin Erbakan University Faculty of Applied Sciences Department of Transportation and Logistics in the 20182019 academic year, it has been investigated whether there is a significant difference between the attitudes and purchasing behavior of the students taking and not taking Green and Reverse Logistics course towards green product.

\section{Green Product, Green Logistics, Reverse Logistics}

In this section, conceptual information about green product, green logistics and reverse logistics will be given. 


\subsection{Green Product}

Green marketing is defined as the efforts of enterprises to design, promote, price and distribute products that will not harm the environment (Jain and Kaur, 2004). Today, with the increasing sensitivity towards the environment, it is seen that consumers tend to convert their purchasing behavior into green purchasing behavior. Green purchasing behavior can be defined as the consumer behavior that protects the environment, minimizes pollution, introduces rules on the use of resources and protects other species. It is also possible to name consumers who care about the environmental impacts of purchasing activities and make rational purchasing decisions in this direction as green consumers.

Green products are defined as products that do not pollute the environment, do not harm living things as much as possible, minimize the consumption of natural resources, and can be recycled or protected. Some important principles are mentioned in order to be successful in green product development strategies (Erbaşlar, 2012). The first is to adopt a direct and serious approach to greening the product and continuously assess the environmental impact of the product throughout its life cycle. The second is to identify a production system that will make recycling maximum, resource waste and waste quantity minimum. The third is to produce high quality, always accessible and safe products in continuous cooperation with consumers. Another is to carry out studies to make consumers prefer these products even though the costs are high.

Pettit and Sheppard (1992) pointed out that consumers need to bear some costs in the transition from non-green behavior to green behavior and stated that abandoned habits, along with benefits, involve costs such as stress and time to learn different behavior. Green consumption requires certain sacrifices, such as paying more for green, accepting defective substitutes for a product, reducing product consumption, and making efforts for some behavioral changes (washing bottles, sorting plastics, binding newspapers, storage, etc.).

\subsection{Green Logistics}

Green logistics aims to reduce environmental pollution and resource use by using advanced logistics technologies that plan and implement transportation, packaging, storage, loading and unloading, circulation operations and other logistics activities. Green logistics can be defined as planning the logistics operations in a way that minimizes the effects on the ecological environment (Boztepe, 2018).

Green logistics management reduces the environmental damages caused by the production and distribution activities of the products. Apart from the internal activities of the company such as product development and production processes, it is also regarded as managing the physical product flows by protecting the environment in the international arena. Supply, distribution, packaging and reverse logistics are among the main elements of green logistics activities (Lai et al., 2012).

\subsection{Reverse Logistics}

Reverse logistics is the reverse movement of the supply chain to manage the flow of completed products or parts to reproduce, recycle, dispose or use resources efficiently (Dowlatshai Shad, 2000).

Reverse logistics is the role of logistics in recycling, waste disposal and management of hazardous materials. 
It includes resource reduction, recycling, material substitution, reuse and disposal of materials (Temur et al., 2015). Reverse logistics involves the distribution of used products through different processes such as collection, separation and recycling.

Reverse supply chain includes the collection, inspection and return of the products to the economy by adding value to the products that are not used due to completing their lifespan or returned for reasons such as poor quality, product recall, warranty and after-sales service (Erol, 2006).

\subsubsection{Recycling}

It is the reuse of wastes under a production procedure for the original purpose or for other purposes, including organic conversion, except for energy recovery. Evaulable materials in solid waste are reintroduced to the economy by recycling (Kaçtığlu and Şengül, 2010). Recycling is the whole of the activities involved in the process of converting wastes into secondary raw materials through specific processes. The recycling process involves the recovery of used products or returned products due to various reasons. The purpose of recycling is to meet some of the raw material requirement from recycled wastes and to provide an economic advantage to enterprises (Öktem, 2016).

\subsubsection{Recovery}

Recovery, which includes the concepts of reuse and recycling, is the conversion of the components contained in the wastes to other products or energy by physical chemical or biochemical methods. Today, products return to the supply chain for reasons such as completing life expectancy, being out of warranty and losing quality features. When the product is returned to the supply chain, reintroducing it to the economy is included in the scope of recovery (Demirel and Gökçen, 2008).

By recovery, the products used as secondary raw materials can be re-used by converting them into the same product or different products. Thus, sustainable and efficient use of resources is possible (Ergülen and Büyükkeklik, 2008).

\section{Literature Review}

Previous studies in the literature are included in this part of the study.

According to the research conducted by Onurlubas on the families living in Istanbul, gender is the first reason that affects consumers' green product purchasing behavior. Environmental awareness varies according to gender. It was revealed that the environmental awareness of women consumers is more developed and they are more likely to buy green products (Onurlubaş, 2016).

Yllmaz and Arslan (2011) 's study on university students is based on students' environmental attitudes and behavior and their willingness to protect the environment. In the study, the effects of gender differences and parental education level on environmental attitudes and behavior were examined and it was seen that the places where the students live, the gender and the education level of the mother were effective in environmental sensitivity. 
In the study named "green human in education, green product in consumption" conducted by Doğan et al. (2013) on Nazilli FEAS and Nazilli Vocational School students, it was aimed to measure the sensitivity of the students to green products. As in previous studies, it was observed that gender, income and education levels of students had an effect on green purchasing behavior. It was found that female students had higher environmental sensitivity than male students. It was concluded that the green product and environmental awareness should be emphasized in the education of the students.

A study was conducted by Çakıroğlu et al. (2019) to determine the attitudes of young consumers towards green products. According to the study on young university students, young consumers are sensitive to environmental problems but do not demonstrate this in their purchasing behavior. The main reason why green product purchasing behavior is low is that green products are expensive compared to other products. Consumers do not agree to pay extra money because the product is green.

A research named "consumer's view on reverse logistics in line with social responsibility" was conducted by Yalci et al. (2017) on consumers living in Edirne province, and a significant relationship was found between social responsibility awareness and green product purchase. As consumers' awareness of social responsibility towards the environment increases, their interest in recycled products also increases. As a result of the study, a significant relationship between social responsibility, green purchasing and recycling activities was revealed.

The studies on green purchasing were examined by Kaufmann et al. (2012) and the factors assumed to affect green purchasing were brought together in their study.

In the study conducted by Aslan and Çınar (2007), the tendency of university students to use environmentally sensitive products on green marketing activities was examined. University students tend to buy products that do not harm the environment. However, in order to raise awareness of all students, organizations such as training, seminars and meetings should be organized and their tendencies towards green product should be increased.

In their study conducted under the name of green marketing as a means of environmental protection, Thapa and Verma (2014) did not find any difference between the demographic characteristics of Dehradun consumers and green product purchasing behavior.

In his research on Romanian consumers, Sima (2014) showed that consumers are willing to buy green products, but the price is very important for them.

As a result of the research carried out by Karaca (2013) on the attitudes of consumers towards green products, it was concluded that with environmental education and various legal regulations, positive behavior changes should be brought to all segments of the society on environmental sensitivity and that environmental awareness can be raised or at least an awareness can be created by keeping environmental problems on the agenda.

Nakiboğlu (2007) presented a comprehensive literature review on reverse logistics and contributed to fill the lack of domestic resources due to the fact that it is a new field in our country. It was stated in the study that reverse logistics is developing due to profitability, social responsibility and ecological reasons. 
Hazen et al. (2012) showed that the satisfaction of consumers with the businesses doing green and reverse logistics activities increases their loyalty levels to these businesses and they are ready to pay more for their products.

In their study in which the green supply chain management practices and internal factors in automobile, electrical / electronic and thermal power plant area in China were analyzed with ANOVA using survey technique, Zhu and Sarkis (2006) stated that designing a product to be sustainable in all stages can minimize ecological damage.

Straughan and Roberts (1999) examined demographic characteristics in defining green consumer behavior in their study with 235 university students in the United States, and concluded that it has an important role. In this study, it is concluded that young people have higher environmental sensitivity than others, that there is a positive relationship between education level and environmental attitudes and behavior, and that women show more sensitive consumption behavior than men.

\section{Research Method and Data Analysis}

In this part of the study, the importance, aim, method and results of the analysis will be given.

\subsection{Importance and Purpose of the Research}

The consequences of environmental damages are appreciable today. Consumers are beginning to realize that purchasing behavior is a direct impact of this loss. Environmental awareness is tried to be increased through trainings on consumers and different campaigns. In Green and Reverse Logistics course prepared for university students, it is aimed to raise awareness about the subject by explaining the current and future applications in detail.

The aim of this study is to investigate whether there is a significant difference between the students taking and not taking the Green and Reverse Logistics course in the Transportation and Logistics Department of Necmettin Erbakan University in 2018-2019 academic year.

\subsection{Research Method}

In this part of the study, the hypothesis and models on which the research is based, the preparation of the questionaire, the sampling method and data collection will be included.

\subsubsection{Research Model and Hypothesis}

The research hypotheses are shared below.

H1: There is a significant average difference between the attitudes of students taking and not taking Green and Reverse Logistics course towards green product.

H2: There is a significant average difference between the green product purchasing behavior of the students taking and not taking Green and Reverse Logistics course. 


\subsubsection{Preparation of the Questionnaire}

The questions in the questionnaire were compiled from the literature and from the Yalci et al. (2017)'s study, which was previously validated. The questionnaire was prepared on the basis of a 25-point Likert scale with 25 questions about consumer attitudes towards recycled products and statements on green purchasing behavior.

In order to measure the difference in perception between the two groups, the criterion for taking or not taking the green and reverse logistics course was added to the questionnaire.

\subsubsection{Sampling Method and Data Collection}

The main population of the study is undergraduate students of Department of Transportation and Logistics, who are studying at Necmettin Erbakan University in 2018-2019 academic year. The curriculum of the Green and Reverse Logistics course determined within the framework of Logistics Training Standards carried out by the Logistics Association (LODER) was applied in the course mentioned in the study. Data were collected by face to face questionnaire method. The questionnaire was conducted in June 2019 during the final exam week when all students were at school. It was conducted before the start of the exam in which all students took their places in the exam hall. The completion time of a questionnaire was 5 minutes.

\subsubsection{Research Limitations}

This study was limited to the students of Necmettin Erbakan University, Department of Transportation and Logistics.

\subsection{Analysis and Interpretation of Data}

Cronbach's alpha coefficient was used to test the reliability of the revised questionnaire. According to the results of the analysis, Cronbach's alpha coefficient was found to be 0.863 and the questionnaire was understood to be reliable.

The number of participants and their distribution by gender are shown in Table 1.

Table 1: Gender Distribution of Participants

\begin{tabular}{lll}
\hline Gender & Number of students $(\mathbf{n})$ & Rate $(\%)$ \\
Female & 103 & 42.4 \\
Male & 140 & 57.6 \\
Total & 243 & 100 \\
\hline
\end{tabular}

As can be seen in Table 1, 243 students participated in the study, $42.4 \%$ of them were female and $57.6 \%$ were male.

The income level of the students participating in the study is given in Table 2. 
Table 2: Income Status of Participants

\begin{tabular}{lll}
\hline Total Household Income & Number of students(n) & Rate(\%) \\
\hline Less than 400 TL & 11 & 4,5 \\
$\mathbf{4 0 0 - 9 9 9}$ & 44 & 18,1 \\
$\mathbf{1 0 0 0 - 1 9 9 9}$ & 30 & 12,3 \\
$\mathbf{2 0 0 0 - 2 9 9 9}$ & 80 & 32,9 \\
$\mathbf{3 0 0 0 - 3 9 9 9}$ & 38 & 15,6 \\
$\mathbf{4 0 0 0 - 4 9 9 9}$ & 18 & 7,4 \\
$\mathbf{5 0 0 0}$ TL and above & 22 & 9,1 \\
Total & 243 & 100 \\
\hline
\end{tabular}

As shown in Table 2, $4.5 \%$ of the students have income less than $400 \mathrm{TL}, 18.1 \%$ have income between 400 and 999 TL, 12.3\% have income between 1000 and 1999 TL, 32.9\% have income 2000 and TL 2999, 15.6\% have income between 3000 and 3999 TL, 7.4\% have income between 4000 and 4999 TL, $9.1 \%$ have income 5000 and above.

Table 3 shows the attendance of the participants to the course.

Table 3: Participants' Status of taking the course

\begin{tabular}{lll}
\hline Status of taking the course & Number of students(n) & Rate $(\%)$ \\
\hline Took & 92 & 37.9 \\
Didn't take & 151 & 62.1 \\
Total & 243 & 100 \\
\hline
\end{tabular}

As can be seen in Table 3, a total of 243 students, including 92 students taking green and Reverse Logistics courses and 151 students not taking the course, participated in the study.

Table 4 shows the mean and p values of the participants' responses to the questions measuring their attitudes towards green products.

Table 4: Participants' Attitudes Towards Green Products

\begin{tabular}{llllll}
\hline Taking the course & $\mathrm{N}$ & $\mathrm{X}$ & $\mathrm{SS}$ & $\mathrm{t}$ & $\mathrm{p}$ \\
\hline Took & 92 & 3,6891 & 0,59123 & 3,337 & $0,001^{*}$ \\
Didn't take & 151 & 3,4079 & 0,66328 & & \\
\hline
\end{tabular}

${ }^{*} \mathrm{p}<0.005$

When the answers of the participants to the questions that measured their attitudes towards green products were examined, it was found that the average scores of the students taking the course were statistically higher than the students who did not take the course $(p<0.005)$. 
Table 5 shows the mean and p values of the participants' responses to the questions that measure their green product purchasing behavior.

Table 5: Participants' Green Product Purchasing Behavior

\begin{tabular}{llllll}
\hline Taking the course & $\mathrm{N}$ & $\mathrm{X}$ & $\mathrm{SS}$ & $\mathrm{t}$ & $\mathrm{p}$ \\
\hline Took & 92 & 3,4761 & 0,59123 & 1,138 & 0,256 \\
Didn't take & 151 & 3,3912 & 0,66328 & & \\
\hline
\end{tabular}

When the answers given by the participants to the questions about green product purchase behavior were examined, no statistically significant difference was found between the average scores of the students who took the course and who did not take the course $(p=0.256)$.

\section{Discussion and Conclusion}

The increase in environmental problems and the sensitivity of individuals to the environment in relation to this have brought about the businesses a social responsibility. Consumers expect businesses to act environmentally sensitive in their production and service activities. In this case, businesses should attach importance to sustainability in order to maintain their long-term profitability. The use of renewable energy and natural energy, the protection of nature and natural resources contribute to the development of the national economy and are important for public health.

The aim of this study is to determine whether there is a meaningful relationship between consumers' taking green and reverse logistics courses and the increase in their sensitivity to the environment. As a result of the survey and analysis, the students who take the green and reverse logistics course understand both the course contents and the importance of environmental damage caused by recycling and logistics processes and their perspectives on environmental issues change. Attitudes of students who took the course towards green products increased significantly compared to the students who did not. They agree to pay more and buy environmentally friendly products compared to non-environmental products, even though the prices of the products obtained from recycling increase. This finding of the study comlies with the studies of Yalçı et al. (2017), Aslan and Çınar (2007) and Karaca (2013) and it is seen that the trainings provided have an effect on increasing environmental awareness of consumers and positively changing their attitudes towards green products. Therefore, consumer attitudes towards green products can be changed positively by increasing training on recycling, recovery and green purchasing.

The public service announcements that encourages the purchase of green products and social awareness can reduce the extent of environmental damage. According to the findings of our study, no significant difference was found between green product purchasing behaviour of the students who took reverse and green logistics courses and the students who did not take the course. According to Doğan et al. (2013) and Sima (2014), there is a dominant relationship between purchasing behavior and income level.

Therefore, the findings in the literature comply with the findings in the study. 
However, it is seen that the average values of the students taking the course $(3,4761)$ are higher than the average values of the students not taking the course (3,3912). Although education cannot directly change purchasing behavior, it can be said to have a positive effect.

This study was conducted only on the students studying at Necmettin Erbakan University Faculty of Applied Sciences, within the scope of time and financial means. Future studies can be performed more extensively on all the students taking the green and reverse logistics course in Turkey. The survey will be applied to all consumers at provincial level and will enable to gain more information about green product purchasing behavior and the perspectives of consumers from different age and occupational groups on recycled products.

\section{References}

Aslan, F., \& Çınar, R. (2007). Yeşil Pazarlama Faaliyetleri Çerçevesinde Kafkas Üniversitesi Öğrencilerinin Çevreye Duyarli Ürünleri Kullanma Eğilimlerini Belirlemeye Yönelik Bir Araştirma. Kafkas Üniversitesi İktisadi ve İdari Bilimler Fakültesi Dergisi, 6(9), 169-184.

Birdoğan, B. (2003). Tersine Lojistik Zorunluluk mu? Kazanç mı?. Dokuz Eylül Üniversitesi İsletme Fakültesi Dergisi, 4(1), 18-39.

Boztepe, H. R. (2018). Yeşil Lojistikte Depo Yeri Seçimi. (Unpublished doctoral dissertation) İstanbul University, İstanbul, Turkey

Çakıroğlu, A. D., Özcan, A., \& Çakıroğlu, M. (2019). Genç Tüketicilerin Yeşil Ürünlere Yönelik Tutumlarının Belirlenmesi: Giresun Üniversitesinde Bir Uygulama. Karadeniz Sosyal Bilimler Dergisi, 11(20), 75-88.

Demirel, Ö. N., \& Gökçen, H. (2008). Geri kazanımlı imalat sistemleri için lojistik ağı tasarımı: literatür araştırması. Gazi Üniversitesi Mühendislik Mimarlık Fakültesi Dergisi, 23(4), 903-912.

Doğan H., Acayıp E. \& Büyükmert A. (2013). Eğitimde Yeşil İnsan Tüketimde Yeşil Ürün: Nazilli İIBF ve Nazilli MYO Öğrencilerine Yönelik Bir Duyarlılık Analizi Çalışması. Sosyal ve Beşeri Bilimler Dergisi, 5 (2), 152-162.

Dowlatshahi, S. (2000). Developing a theory of reverse logistics. Interfaces, 30(3), 143-155.

Erbaşlar, G. (2012). Yeşil Pazarlama. Mesleki Bilimler Dergisi (MBD), 1(2), 94-101.

Ergülen, A. \& Büyükkeklik, A. (2008). Sürdürülebilir Kalkınmanın Ekonomik ve Çevre Boyutları Açısından Atık Yönetimi ve E-Atıklar. Niğde Üniversitesi İ.I.B.F. Dergisi, $1(2), 14-21$

Erol, İ., Velioğlu, M. N., \& Şerifoğlu, F. S. (2006). AB uyum yasaları ve sürdürülebilir kalkınma bağlamında tersine tedarik zinciri yönetimi: Türkiye'ye yönelik araştırma firsatları ve önerileri. Iktisat Isletme ve Finans, 21(244), 86-106.

Hazen, B. T., Wu, Y., Cegielski, C. G., Jones-Farmer, L. A., \& Hall, D. J. (2012). Consumer reactions to the adoption of green reverse logistics. The International Review of Retail, Distribution and Consumer Research, 22(4), 417-434.

Jain, S. K., \& Kaur, G. (2004). Green marketing: An attitudinal and behavioural analysis of Indian consumers. Global Business Review, 5(2), 187-205.

Kaçtıŏlu, S., \& Şengül, Ü. (2010). Erzurum kenti ambalaj atiklarinin geri dönüşümü için tersine lojistik aği tasarimi ve bir karma tamsayili programlama modeli. Atatürk Üniversitesi İktisadi ve İdari Bilimler Dergisi, 24(1), 89-112. 
Karaca, S. (2013). Tüketicilerin Yesil Ürünlere Iliskin Tutumlarinin Incelenmesine Yönelik Bir Arastirma. Ege Akademik Bakıs, 13(1), 99.

Kaufmann, H. R., Panni, M. F. A. K., \& Orphanidou, Y. (2012). Factors affecting consumers' green purchasing behavior: An integrated conceptual framework. Amfiteatru Economic Journal, 14(31), 50-69.

Lai, K. H., \& Wong, C. W. (2012). Green logistics management and performance: Some empirical evidence from Chinese manufacturing exporters. Omega, 40(3), 267-282.

Nakiboğlu, G. (2007). Tersine Lojistik: Önemi ve Dünyadaki Uygulamaları. Gazi Üniversitesi İktisadi ve Ídari Bilimler Fakültesi Dergisi, 9(2), 181-196.

Onurlubaş, E. (2016). Tüketicilerin Yeşil Ürün Satın Alma Davranışlarını Etkileyen Faktörler. Yalova Sosyal Bilimler Dergisi, 6(11), 70-106.

Öktem, B. (2016). Geri Dönüşümün Üretim Maliyetlerine Etkisi ve Kağıt Karton Sektöründe Bir Uygulama. Çankırı Karatekin Üniversitesi İ̈BF Dergisi, 6(1), 359-381.

Pettit, D., \& PAUL, J. (1992). It's Not Easy Being Green: The Limits of Green Consumerism in Light of the Logic. Queen's Quarterly, 99, 2.

Sima, V. (2014). Green Behaviour of the Romanian Consumers. Economic Insights-Trends \& Challenges, 66(3).

Straughan, R. D., \& Roberts, J. A. (1999). Environmental segmentation alternatives: a look at green consumer behavior in the new millennium. Journal of consumer marketing, 16(6), 558-575.

Temur, G. T., Ayvaz, B., \& Bolat, B. (2015). Tersine Lojistik Yönetimi Dünya'da ve Türkiye’de Durum, 1. Bask1, Nobel Yayınları, İstanbul.

Thapa, S. H. A. L. I. N. I., \& Verma, S. H. I. K. H. A. (2014). Analysis of green marketing as environment protection tool: a study of consumer of dehradun. International Journal of Research in Commerce \& Management, 5(9), 78-84.

Yalçı, E. B., Altuğ, N., \& Akın, Y. K. (2017). Tüketicilerin Sosyal Sorumluluk Bilinci Doğrultusunda Tersine Lojistiğe Bakış Açıları. Akademik Bakış Uluslararası Hakemli Sosyal Bilimler Dergisi, (60), 383-395.

Yılmaz, V. \& Arslan T. (2011). Üniversite Öğrencilerinin Çevre Koruma Vaatleri ve Çevre Dostu Tüketim Davranışlarının İncelenmesi. Anadolu Üniversitesi Sosyal Bilimler Dergisi, 11 (3), 1-10.

Zhu, Q., \& Sarkis, J. (2006). An inter-sectoral comparison of green supply chain management in China: drivers and practices. Journal of Cleaner Production, 14(5), 472-486. 